DOI: 10.21802/artm.2019.3.11.28.

УДК 616.133:616.125+616.12-008.331/.1:79-053.8

\title{
ОСОБЛИВОСТІ ПОКАЗНИКІВ СТРУКТУРНОГО СТАНУ СОННИХ АРТЕРІЙ У ПАЦІЕНТІВ ІЗ ГІПЕРТОНІЧНОЮ ХВОРОБОЮ ЗАЛЕЖНО ВІД РІВНЯ ГАЛЕКТИНУ-3 І АЛЬДОСТЕРОНУ
}

\author{
В.П. Іванов, Т.П. Онищук
}

Вінницький національний медичний університет ім. М.І. Пирогова, кафедра терапевтичних дисциплін та сімейної медицини факультету післядипломної освіти,

м. Вінниия, Україна,

ORCID ID: 0000-0002-3026-0319,

ORCID ID: 0000-0002-6268-4984,

e-mail:vra4ixa@ukr.net

Резюме. У статті було проведено аналіз структурного стану сонних артерій у пацієнтів із гіпертонічною хворобою (ГХ), залежно від плазмових рівнів галектину-3 і альдостерону. 3 цією метою проведено комплексне обстеження рівної кількості (по 80) осіб хворих на ГХ ІІ. Обстежуваних, що включали в дослідження, було поділено на 4 групи залежно від віку. У групу молодого віку ввійшли особи чоловічої та жіночої статі (по 40 осіб) віком 18-44 роки; групи середнього віку склали чоловіки та жінки (по 40) віком від 45-60 років. Загальна кількість обстежених - 160 осіб. Групу контролю склало 27 відносно здорових осіб. Середній вік та частка пацієнтів різного віку достовірно не відрізнялась. Верифікацію діагнозу ГХ проводили на підставі чинних критеріїв та рекомендацій.

Рівень альдостерону та галектину-3 визначали за допомогою імуноферментного аналізу (ІФА). Структурний стан сонних артерій (СА) визначали на підставі оцінки величини товщини інтима-медіа (TIM).

Проведене дослідження встановило, що в пацієнтів з ГХ молодого і середнього віку структурне ремоделювання сонних артерій не виявляє асоціацій зі статтю і віковим цензом пацієнтів. У разі відносно високого (BВ) рівня галектину-3 на відміну від відносно низького (BН) і відносно помірного (ВП) визначали суттєве збільшення величини ТIM ( 1,00 проти 0,88 і 0,90 мм, p=0,02 і 0,04 відповідно) і частоти випадків 3 TIM >0,9 мм (61,4 \% проти $34,9 \%$ i 41,1\%, p=0,01 і 0,03 відповідно). У свою чергу, аналогічний аналіз даних, залежно від плазмового рівня альдостерону, продемонстрував дещо інші статистичні закономірності. Спостерігалось, що величина ТІМ і відсоток випадків з ТІМ >0,9 мм були достовірно вищими при $\mathrm{BB}$, у порівнянні лише з $\mathrm{BH}$ рівнем нейрогормону ( 1,00 проти 0,88 мм, $\mathrm{p}=0,01$ і $61 \%$ проти $32,5 \%$, $\mathrm{p}=0,01$ відповідно).

Ключові слова: гіпертонічна хвороба, галектин-3, альдостерон, товщина інтима-медіа, сонні артерії.

Вступ. Ремоделювання серця та судин - невід'ємний атрибут при артеріальній гіпертензії (АГ), в основі якого лежать структурні, гемодинамічні та генетичні механізми [1]. Структурне ремоделювання серця зумовлює реорганізацію компонентів стінки лівого шлуночка, розвиток міокардіальної дисфункції i різних порушень серцевого ритму, що суттєво ускладнює перебіг і прогноз у такого масиву хворих [2].

Поряд із значними досягненнями науковців у сфері ремоделювання серця велика увага дослідників привернута також на структурні зміни крупних судин, а саме - сонних артерій. Згідно з даними рекомендацій Американської асоціації серця (American Heart Association), визначення комплексу товщини інтима-медіа (ТIM) сонних артерій має особливе значення в первинній профілактиці кардіоваскулярних наслідків [3, 4] є неінвазивним методом виявлення субклінічного атеросклерозу [5] та може визначати індивідуальний ступінь вираженості кардіальної патології [3].

Окрім значних напрацювань дослідників усього світу в сфері перебудови серця та судин при АГ, достатньо сумлінно вивчаються і біомаркери, що можуть впливати на вищевказані процеси. Мова йде про галектин-3 та альдостерон, два нейрогормони, що, згідно з даними літератури та великої кількості досліджень, володіють можливостями впливу на процеси активації фіброзування та перебудови серця та судин [6, 7] та можуть бути використані для поліпшення діагностики та виявлення хворих із АГ.

Мета дослідження. Метою нашої роботи було визначення структурного стану сонних артерій на підставі оцінки величини ТIM у пацієнтів, що хворіють на ГХ залежно від рівня галектину-3 та альдостерону.

Матеріали та методи. Відповідно до мети дослідження проведено комплексне обстеження 160 хворих із ГХ чоловічої та жіночої статі віком від 19 до 60 років (у середньому 44,5 $\pm 0,9$, медіана - 46 й інтерквартильний розмах - 37 і 55), що хворіли на ГХ II стадії та знаходились у відділенні денного стаціонару Хмельницького обласного кардіологічного диспансеру (ХОКД). Усі 160 хворих із ГХ ІІ стадії були розподілені на групи залежно від віку: хворі молодого (18-44 років) та середнього (45-60 років) віку (по 40 осіб в кожній групі). Групу контролю склали 27 відносно здорових пацієнтів, віком 19-56 
років, серед яких 16 (59,3\%) чоловіків та 11 жінок (40,7\%), середній вік (у середньому 42,2 1,6 , медіана - 44 й інтерквартильний розмах - 35 і 52). За допомогою клініко-інструментальних методів дослідження у групі контролю було виключено суттєву соматичну патологію. У групах хворих, що були включені в дослідження, не визначали достовірності в різниці середнього віку $(\mathrm{t}=1,25 ; \mathrm{p}=0,11)$. Вікова та статева структура контрольної та основної груп обстежуваних була статистично однорідною.

Діагноз АГ верифікували на підставі клінікоінструментального обстеження відповідно до наказу MO3 України № 384 від 24.05.2012 р., згідно з рекомендаціями Української асоціації кардіологів і клінічними рекомендаціями Європейської асоціації гіпертензії та Свропейської асоціації кардіологів (2016). Усі хворі підписали інформовану згоду на участь у дослідженні.

Забір крові для визначення біомаркерів (альдостерону та галектину-3) проводився натще в положенні лежачи о 8:30 (після 20-ти хвилинного відпочинку) із кубітальної вени у кількості 5 мл вакутайнером з ЕДТА (1 мг на 1 мл крові). Цільну кров центрифугували протягом 20 хв (при 1600 об/хв). Отриману плазму переносили у поліпропіленові пробірки типу Eppendorf. Матеріал зберігали при температурі $30^{\circ} \mathrm{C}$ протягом максимум 8 місяців до власне дослідження. Гемолізовані сироватки не включали у дослідження. Рівень альдостерону визначали за допомогою імуноферментного аналізу (IФА) методом ELISA 3 використанням реактивів IBL International $\mathrm{GmbH}$ (Канада). Референтними значеннями вважали рівень альдостерону 40-160 пг/мл.

Рівень галектину-3 в сироватці крові визначали за допомогою методу твердофазного ІФА 3 використанням набору реактивів Human Galectin-3 Platinum Elisa (Bender MedSystems GmbH, Австрія).

За допомогою варіаційної статистики в основній групі хворих було виділено рівні нейрогормонів. Для галектину-3: 1-ий рівень - відносно низький $(\mathrm{BH})(<1,1$ пг/мл), 2-ий - відносно помірний (ВП) (від 1,1 до 2,4 пг/мл) і 3-ій - відносно високий (BВ) рівень ( $>2,4$ пг/мл). Так, ВН рівень нейрогормону був визначений нами в 43 (26,9\%), ВП - у 72 (45,0\%) і ВВ - у 45 (28,1\%) пацієнтів відповідно. Для альдостерону: 1-ий - відносно низький $(\mathrm{BH})(<$ 206 пг/мл), 2-ий - відносно помірний (ВП) (від 206 до 325 пг/мл) і 3-ій - відносно високий (BВ) рівень (> 325 пг/мл). Так, ВН рівень гормону був визначений у $40(25,0 \%)$, ВП - у $79(49,4 \%)$ і ВВ - у $41(25,6 \%)$ пацієнта відповідно.

Структурний стан сонних артерій (СА) визначали на підставі оцінки величини товщини інтима-медіа (ТIM), в положенні лежачи на спині. Визначення TIM проводили на апараті ALOKA SSD5000 ProSound PHD (Японія). У трьох площинах проводили сканування сонних артерій. Датчик розміщували по передньому краю грудиноключичнососкоподібного м'яза. Для візуалізації внутрішніх i зовнішніх сонних артерій отримували зображення біфуркації загальної сонної артерії, якій відповідає ділянка 3 більш широким діаметром судини. При дослідженні внутрішньої сонної артерії датчик повертали в латеральний бік, а зовнішньої сонної артерії у внутрішній. Товщину КІМ визначали на $1-1,5$ см вище біфуркації загальної сонної артерії (ЗСА) по задній стінці та оцінювали в зоні його максимального візуального потовщення. Діагностичним критерієм потовщення КІМ вважали, згідно з рекомендаціями Європейської спільноти кардіологів, показник $\geq 0,9$ мм, наявність атеросклеротичної бляшки визнавали при потовщенні комплексу інтима-медіа на 1,5 мм і більше [8].

Статистичну обробку результатів дослідження проводили за допомогою стандартних методів із застосуванням пакета прикладних програм StatSoft "Statistica" v.12 згідно з рекомендаціями [9]. Кількісні величини представлені у вигляді медіани й інтерквартильного розмаху (25 і 75 персантиль), у разі відносних величин у вигляді (\%). Порівняння кількісних величини у групах за допомогою U-критерію Манна-Уїтні і Kruskal-Wallis ANOVA test, відносних величин - за критерієм $\chi^{2}$. Для аналізу спрямованості та сили зв'язку між плазмовими рівнями нейрогормонів використовували непараметричний кореляційний аналіз Спірмена (R).

Результати дослідження. Достатньо великий інтерес для нас представив аналіз величини ТІМ сонних артерій, а також випадків збільшення його (>0,9 мм) у різних клінічних групах хворих (табл. 1). Нами зафіксовано, що в 43,6-48,8 \% хворих різних груп спостерігали ТIM >0,9 мм. Останнє демонструвало наявність структурного ремоделювання сонних артерій у більшої третини обстежених нами пацієнтів. Натомість результати проведеного аналізу показали відсутність суттєвих відмінностей у проаналізованих показниках у виділених групах хворих. Слід було думати, що в пацієнтів з ГХ молодого і середнього віку структурне ремоделювання сонних артерій не виявляє асоціацій зі статтю та віковим цензом пацієнтів.

Наступним кроком в ході нашого дослідження стало проведення аналізу структурного стану сонних артерій (табл. 2) у пацієнтів 3 ГХ молодого і середнього віку залежно від плазмового рівня галектину-3 i альдостерону. Слід сказати, що в жодного 3 обстежених нами пацієнтів ми не реєстрували наявність атеросклеротичних бляшок у басейні сонної артерії, тому структурний стан останніх визначали за величиною TIM.

Було виявлено, що як величина ТІМ, так і відсоток випадків з TIM >0,9 мм мали певну залежність від величини плазмового рівня галектину-3. Так, у разі ВВ, на відміну від ВН і ВП рівня нейрогормону, визначалось суттєве збільшення величини TIM (1,00 проти 0,88 і 0,90 мм, p=0,02 і 0,04 відповідно) і частоти випадків з ТІМ > 0,9 мм (61,4 \% проти $34,9 \%$ і 41,1 \%, p=0,01 і 0,03 відповідно). Порівняння даних після попереднього вирівнювання груп за величиною альдостерону показало, що величина ТIM $(0,95$ проти 0,85 мм, p=0,01) і частота випадків з ТІМ $>0,9$ мм $(51,1 \%$ проти $27,1 \%, \mathrm{p}=0,02)$ були суттєво вищими при рівні галектину-3 > 2,0 пг/мл, у порівнянні з рінем $\leq 2,0$ пг/мл. 
Таблиця 1

Величина ТІМ сонних артерій та кількість хворих з ТІМ > 0,9 мм у пацієнтів з ГХ різного віку і статі

\begin{tabular}{|c|c|c|}
\hline Категорії хворих & Величина ТІМ, мм & К-ть хворих з TIM > 0,9 мм \\
\hline Чоловіки $(\mathrm{n}=80)$ & $0,99(0,78 ; 1,13)$ & $38(47,5 \%)$ \\
\hline Жінки $(\mathrm{n}=80)$ & $0,93(0,70 ; 1,10)$ & $35(43,8 \%)$ \\
\hline $\mathrm{P}$ & 0,35 & $34(44,7 \%)$ \\
\hline Молодий вік $(\mathrm{n}=76)$ & $0,95(0,70 ; 1,15)$ & $39(46,4 \%)$ \\
\hline Середній вік $(\mathrm{n}=84)$ & $0,97(0,80 ; 1,10)$ & 0,83 \\
\hline $\mathrm{P}$ & 0,46 & $17(45,9 \%)$ \\
\hline Чоловіки молодого віку $(\mathrm{n}=37)$ & $0,97(0,80 ; 1,15)$ & $21(48,6 \%)$ \\
\hline Жінки молодого віку $(\mathrm{n}=39)$ & $0,94(0,70 ; 1,15)$ & $18(43,9 \%)$ \\
\hline Чоловіки середнього віку $(\mathrm{n}=43)$ & $1,00(0,75 ; 1,10)$ & $>0,60$ \\
\hline Жінки середнього віку $(\mathrm{n}=41)$ & $0,93(0,80 ; 1,00)$ & $>0,40$ \\
\hline $\mathrm{P}$ &
\end{tabular}

Структурний стан сонних артерій у паціснтів з ГХ молодого і середнього віку залежно від рівня галектину-3 і альдостерону

\begin{tabular}{|c|c|c|}
\hline Категорії хворих & Величина ТІМ, мм & $\begin{array}{c}\text { К-ть хворих } \\
\text { 3 ТІМ >0,9 мм }\end{array}$ \\
\hline \multicolumn{3}{|c|}{ Залежно від плазмового рівня галектину-3 } \\
\hline 1. ВН $<1,1$ пг/мЛ $(\mathrm{n}=43)$ & $0,88(0,70 ; 0,94)$ & $15(34,9 \%)$ \\
\hline 2. ВП - 1,1-2,4 пг/мл $(\mathrm{n}=73)$ & $0,90(0,75 ; 1,06)$ & $30(41,1 \%)$ \\
\hline 3. ВВ $>2,4$ пг/мЛ $(\mathrm{n}=44)$ & $1,00(0,84 ; 1,20)$ & $27(61,4 \%)$ \\
\hline $\begin{array}{c}\text { P за Kruskal-Wallis ANOVA test i } \\
\text { критерієм } \chi^{2}\end{array}$ & $\begin{array}{l}\mathrm{P} 1-3=\mathbf{0 , 0 2} \\
\mathrm{p} 2-3=\mathbf{0 , 0 4}\end{array}$ & $\begin{array}{l}\mathrm{P} 1-3=\mathbf{0 , 0 1} \\
\mathrm{p} 2-3=\mathbf{0 , 0 3}\end{array}$ \\
\hline \multicolumn{3}{|c|}{ Залежно від рівня галектину-3 після вирівнювання груп за величиною альдостерону } \\
\hline$\leq 2,0$ пг/мл $(\mathrm{n}=48)$ & $0,85(0,70 ; 0,98)$ & $13(27,1 \%)$ \\
\hline$>2,0$ пг/мл $(\mathrm{n}=47)$ & $0,95(0,80 ; 1,15)$ & $24(51,1 \%)$ \\
\hline P за Mann-Whitney U test і критерієм $\chi^{2}$ & $\mathbf{0 , 0 1}$ & $\mathbf{0 , 0 2}$ \\
\hline \multicolumn{3}{|c|}{ Залежно від плазмового рівня альдостерону } \\
\hline 1. ВН $<206$ пг/мл $(\mathrm{n}=40)$ & $0,88(0,70 ; 1,10)$ & $13(32,5 \%)$ \\
\hline 2. ВП - 206-325 пг/мл (n=79) & $0,93(0,80 ; 1,10)$ & $34(43,0 \%)$ \\
\hline 3. $\mathrm{BB}>325$ пг/мл $(\mathrm{n}=41)$ & $1,00(0,88 ; 1,23)$ & $25(61,0 \%)$ \\
\hline $\begin{array}{c}\text { P за Kruskal-Wallis ANOVA test i } \\
\text { критерієм } \chi^{2}\end{array}$ & $\mathrm{P} 1-3=\mathbf{0 , 0 1}$ & $\begin{array}{l}\mathrm{P} 1-3=\mathbf{0 , 0 1} \\
P 2-3=0,06\end{array}$ \\
\hline \multicolumn{3}{|c|}{ Залежно від рівня альдостерону після вирівнювання груп за величиною галектину-3 } \\
\hline$\leq 290$ пг/мл $(\mathrm{n}=40)$ & $0,90(0,75 ; 1,10)$ & $17(42,5 \%)$ \\
\hline$>290$ пг/мл $(\mathrm{n}=47)$ & $0,94(0,80 ; 1,15)$ & $21(44,7 \%)$ \\
\hline P за Mann-Whitney U test і критерієм $\chi^{2}$ & НД & НД \\
\hline
\end{tabular}

У свою чергу аналогічний аналіз даних залежно від плазмового рівня альдостерону продемонстрував дещо інші статистичні закономірності. Спостерігалось, що величина TIM і відсоток випадків 3 TIM > 0,9 мм були достовірно вищими при BB, у порівнянні лише 3 ВН рівнем нейрогормону (1,00 проти 0,88 мм, p=0,01 i 61,0\% проти 32,5\%, p=0,01 відповідно). Натомість аналіз, проведений після попереднього вирівнювання груп за величиною галектину-3, показав абсолютну відсутність залежності величини ТIM і частоти випадків 3 структурним ураженням сонних артерій у групах з різним рівнем альдостерону ( $\leq 290$ і > 290 пг/мл). Таким чином, отримані дані свідчили про відсутність безпосереднього зв'язку плазмового рівня альдостерону з характером структурного ураження сонних артерій у пацієнтів 3 ГХ ІІ стадії молодого і середнього віку.

\section{Висновки:}

1. У пацієнтів з ГХ молодого і середнього віку структурне ремоделювання сонних артерій не виявляє асоціацій з статтю і віковим цензом.

2. Встановлено, що у разі відносно високого (ВВ) рівня галектину-3 на відміну від відносно низького (ВН) і відносно помірного (ВП) визначали суттєве збільшення величини ТІМ (1,00 проти 0,88 і 0,90 мм, $\mathrm{p}=0,02$ i 0,04 відповідно) і частоти випадків 3 ТІМ $>0,9$ мм (61,4 \% проти 34,9\% i 41,1\%, p=0,01 i 0,03 відповідно).

3. У свою чергу аналогічний аналіз даних залежно від плазмового рівня альдостерону продемонстрував дещо інші статистичні закономірності. Спостерігалось, що величина ТIM і відсоток випадків з ТІМ $>0,9$ мм були достовірно вищими при ВВ, у порівнянні лише 3 ВН рівнем нейрогормону (1,00 проти 0,88 мм, p=0,01 і 61 \% проти 32,5\%, p=0,01 відповідHO). 
References:

1. Barnet OIu, Zaremba YeKh, Kyiak YuK, Kobzarenko OA. Remodeliuvannia miokarda pry arterialnii hipertenzii ta yoho klinichne znachennia. Liky Ukrainy plius. 2010; 4:37-40 [in Ukrainian].

2. Xiao-Yan Wu; Rong Bai; Songnan Wen; Xin Du; Jianzeng Dong; Chang-Sheng Ma; Song-Nan Li. Plasma galectin-3 elevated in patients with lone persistent and paroxysmal atrial fibrillation and associated with left atrial enlargement. JACC. 2014

3. Lavryniuk VIe. Stan sonnykh arterii u khvorykh na pochatkovykh stadiiakh kaltsynuiuchoi khvoroby sertsia. Tavrycheskyi medyko-byolohycheskyi vestnyk. 2013; 16.1(2):115-118 [in Ukrainian].

4. Greenland P, Alpert GS, Beller GA et al. American College of Cardiology Foundation; American Heart Association. 2010 ACC/AHA guidelines for assessment of cardiovascular risk in asymptomatic adults: executive summury: a report of the American College of Cardiology Foundation. American Heart Association Task Force on Practice Guidelines. J. Amer. Coll. Cardiology.2010; 56:2182-2199.

5. Mazur SH. Vikovi osoblyvosti stanu sonnykh arterii ta tserebralnoi hemodynamiky $\mathrm{u}$ khvorykh, shcho perenesly ishemichnyi insult, zalezhno vid pivkulovoi lokalizatsii vohnyshcha. Promeneva diahnostyka, promeneva terapiia.2012; 4:5-16 [in Ukrainian].

6. Calvier L, Miana M, Reboul $\mathrm{P}$ et al. Galectin-3 Mediates Aldosterone-Induced Vascular Fibrosis. Arteriosclerosis, Thrombosis, and Vascular Biology.2013; 33:67-75.

7. De Boer RA, van Veldhuisen DJ, Gansevoort RT et al. The fibrosis marker galectin-3 and outcome in the general population. J. Intern. Med.2012; 272:55-64.

8. Leliuk VH. Ultrazvukovaia anhyolohyia.Kyev:Real Taim,2012. P.67-68 [in Ukrainian].

9. Rebrova OJu. Statisticheskij analiz medicinskih dannyh. Prymenenye paketa prikladnyh prohramm STATISTICA. Moskva:MedjaSfera, 2006. P.312 [in Russia].

\section{УДК 616.133:616.125 + 616.12-008.331/.1:79-053.8 \\ ОСОБЕННОСТИ ПОКАЗАТЕЛЕЙ СТРУКТУР- НОГО СОСТОЯНИЯ СОННЫХ АРТЕРИЙ У ПАЦИЕНТОВ С ГИПЕРТОНИЧЕСКОЙ БОЛЕЗНЬЮ В ЗАВИСИМОСТИ ОТ УРОВНЯ ГАЛЕКТИНА-3 И АЛЬДОСТЕРОНА}

\section{В.П. Иванов, Т.П. Онищук}

Винницкий национальный медицинский университет им. Н.И. Пирогова, кафедра терапевтических дисциплин и семейной медицинь факультета последипломного образования,

2. Винница, Украина,

ORCID ID: 0000-0002-3026-0319,

ORCID ID: 0000-0002-6268-4984,

e-mail:vra4ixa@ukr.net

Резюме. В статье был проведен анализ структурного состояния сонных артерий у пациентов с гипертонической болезнью (ГБ), в зависимости от плазменных уровней галектина-3 и альдостерона. С этой целью проведено комплексное обследование равного количества (по 80) лиц больных с ГБ ІІ стадии. Обследуемые были разделены на 4 группы в зависимости от возраста. В группу молодого возраста вошли лица мужского и женского пола (по 40 человек) в возрасте 18-44 лет; группу среднего возраста составили мужчины и женщины (по 40) в возрасте 45-60 лет. Общее количество обследованных - 160 человек. Группу контроля составило 27 относительно здоровых лиц. Средний возраст и доля пациентов разного возраста достоверно не отличалась. Верификацию диагноза ГБ проводили на основании действующих критериев и рекомендаций.

Уровень альдостерона и галектина-3 определяли с помощью иммуноферментного анализа (ИФА).

Структурное состояние сонных артерий (CA) определяли на основании оценки величины толщины интима-медиа (ТИМ).

Проведенное исследование показало, что у пациентов с ГБ молодого и среднего возраста структурное ремоделирования сонных артерий не проявляет ассоциаций с полом и возрастом. В случае относительно высокого (OB) уровня галектина-3 в отличие от относительно низкого $(\mathrm{OH})$ и относительно умеренного (ОУ) определяли существенное увеличение величины ТИМ (1,00 против 0,88 и 0,90 мм, $p=0,02$ и 0,04 соответственно) и частоты случаев с ТИМ $>0,9$ мм (61,4 \% против 34,9 \% и 41,1 \%, p=0,01 и 0,03 соответственно). В свою очередь, аналогичный анализ данных, в зависимости от плазменного уровня альдостерона, продемонстрировал несколько иные статистические закономерности. Наблюдалось, что величина ТИМ и проценты случаев с ТИМ $>0,9$ мм были достоверно выше при ОВ, по сравнению только c $\mathrm{OH}$ уровнем нейрогормона (1,00 против 0,88 мм, $\mathrm{p}=0,01$ и $61 \%$ против $32,5 \%, \mathrm{p}=0,01$ соответственно).

Ключевые слова: гипертоническая болезнь, галектин-3, альдостерон, толщина интима-медиа, сонные артерии.

\section{UDC 616.133:616.125+616.12-008.331/.1:79-053.8 CHARACTERISTICS OF INDICES OF THE CAROTID ARTERIES STRUCTURAL CONDITION IN PATIENTS WITH HYPERTEN- SION DEPENDING ON GALECTIN-3 AND ALDOSTERONE LEVELS}

\section{V.P. Ivanov, T.P. Onyshchuk}

National Pirogov Memorial Medical University, Department of Therapeutic Disciplines and Family Medicine of the Faculty of Postgraduate Education, Vinnytsya, Ukraine, ORCID ID:0000-0002-3026-0319, ORCID ID: 0000-0002-6268-4984, e-mail:vra4ixa@ukr.net 
Abstract. The article analyzes the structural condition of the carotid arteries in patients suffering from hypertension stage 2 , depending on the plasma levels of galectin-3 and aldosterone in plazma. For this purpose, a complete physical examination of an equal number (80) of men and women with hypertension stage 2 was conducted regardless of the degree.

Patients with hypertension, who participated in the study, were divided into 4 groups depending on age: groups of young and middle age. The group of young patients included men and women ( 40 people), aged 18 to 44 years. The middle-aged groups included men and women (40 people), aged 45 to 60 years. The total number of the examined patients which we surveyed and were included in the study was 160 persons. The control group included 27 relatively healthy persons (male and female). The average age and the percentage of young and middleaged patients did not differ significantly. Verification of the diagnosis of hypertension was carried out on the basis of the existing criteria and recommendations.

Aldosterone level was determined by the enzyme-linked immunosorbent assay ELISA using reagents of IBL International GmbH (Canada). Aldosterone level of $40-160 \mathrm{pg} / \mathrm{ml}$ was considered as the reference values.

The level of galectin-3 in serum was determined by the solid-phase enzyme linked immunosorbent assay using a set of reagents of Human Galectin-3 Platinum Elisa (Bender MedSystems GmbH, Austria).

Blood sampling for the determination of biomarkers (aldosterone and galectin-3) was performed on an empty stomach at 8:30 (after a 20-minute rest) from a cubital vein in an amount of $5 \mathrm{ml}$ EDTA evacuator (1 mg per $1 \mathrm{ml}$ of blood). Whole blood was centrifuged for 20 min (at $1600 \mathrm{rpm}$ ). The resulting plasma was transferred into Eppendorf-type polypropylene tubes. The material was stored at $-300 \mathrm{C}$ for a maximum of 8 months prior to the study. Hemolyzed sera were not included in the study.

The structural condition of the carotid arteries (CA) was determined according to the assessment of the intima-media thickness (IMT). IMT assessment was conducted be means of ALOKA SSD-5000 ProSound PHD (Japan) apparatus.

It has been found that none of the examined patients had registered atherosclerotic plaques in the carotid artery, therefore the structural condition of the latter was determined by means of IMT measurement.

The conducted study determined that in case of relatively high (RH) level of galectin-3 in contrast to relatively low (RL) and relatively moderate (RM) levels there was determined a significant increase in IMT measurement ( 1.00 versus 0.88 and $0.90 \mathrm{~mm}, \mathrm{p}=0.02$ and 0.04 , respectively) and frequency of cases with IMT $>0.9 \mathrm{~mm}$ $(61.4 \%$ versus $34.9 \%$ and $41.1 \%, p=0.01$ and 0.03 , respectively). In contrast, a similar data analysis, depending on the plasma level of aldosterone, demonstrated slightly different statistical patterns. It has been observed that the IMT measurement and the percentage (\%) of cases with IMT $>0.9 \mathrm{~mm}$ were definitely higher with $\mathrm{RH}$ level, compared only with RL level of neurohormone (1.00 versus $0.88 \mathrm{~mm}, \mathrm{p}=0.01$ and $61 \%$ versus $32.5 \%, \mathrm{p}=0.01$, respectively).

Keywords: hypertension, galectin-3, aldosterone, intima-media thickness, carotid arteries. 